\title{
3-methylglutaconic aciduria type 3
}

INSERM

\section{Source}

INSERM. (1999). Orphanet: an online rare disease and orphan drug data base. $\underline{3-}$ methylg/utaconic aciduria type 3. ORPHA:67047

3-methylg lutaconic aciduria type III (MGA III) is an organic aciduria characterised by the association of optic atrophy and choreoathetosis with 3-methylglutaconic aciduria. 